UDC 811.138.1’42

\author{
Nadiia Pozhydaieva \\ $\mathrm{PhD}$ in Germanic languages, \\ Associate Professor \\ Horlivka Institute for Foreign Languages \\ Donbass State Pedagogical University \\ Bakhmut, Ukraine \\ ORCID ID 0000-0002-3076-2685 \\ ponad2008@ukr.net
}

\title{
CONTRIBUTION OF ENGLISH LINGUA FRANCA TO STABLE CROSS-CULTURAL COMMUNICATION
}

\begin{abstract}
The article deals with the phenomenon of English lingua franca (ELF) and its rapid expansion on the territory of Europe influencing cross-cultural communication. With globalization processes growing worldwide, cross-cultural awareness is bound to be enhancing the use of a common language for international interactions. The expanding circle of English incorporates its variety which is used for crosscultural communication exclusively by non-native speakers. There is no one who speaks English lingua franca as a native language. Thus, the analysis of its functional value should be focused on the success of communication rather than on the number of deviations from the norms. The functional range of ELF allows its users to exploit it more liberally without being bound to any specific norms or regulations. The paper illustrates the influence of the linguistic situation in Europe on the formation of a new type of the language of intercultural communication (English lingua franca) with reference to the professional culture of seafarers. It has been taken into consideration that international seafarers use ELF for their communication, both oral and written, thus contributing to the process of de-standardization of the English language. The content analysis of certain texts (extracts from seafarers' professional correspondence) shows some independence of communicative effect from correct / incorrect grammatical and structural form of the utterance based on the use of professional sublanguage and its implicit effect. English lingua franca is promptly becoming an effective communicative instrument of mighty force. It represents a certain cultural segment and enjoys sustainable development.
\end{abstract}

Keywords: English lingua franca; linguistic situation; expanding circle; effective communicative event; deviation from norms; professional culture; communication instrument.

\section{INTRODUCTION}

Over a couple of the last decades, English has been expanding across the world rapidly, and at the moment its geography is deep and wide. The nature of English as an international language proves that it is more often used as a second language rather than the native speakers' language. It has become a new means of cross-cultural communication. The essence of the English language belonging to "expanding circle" (Kachru, 1989, p. 16) is promoting worldwide awareness of inevitability and positive effect of bilingualism in a new globalized world. Statistics suggests that English is a valuable linguistic resource given the extent to which the language is used on a daily basis all over the world for intercultural communication between people of diverse language and cultural backgrounds.

As the globalization processes are growing and spreading over all spheres of life, and international interactions become commonplace, the intercultural awareness is bound to be enhancing the use of a common language for such interactions. The communicative value of English cannot be overestimated given the role it plays in various spheres, like politics, technology, media and entertainment, travel, education and international safety standards. The social status of English has changed lately and now more often than not it is used solely by non-native speakers as a second language for their own needs. A common language for non-native speakers with different cultural and national background, which enables communication, is a lingua franca. English is used as a lingua franca in numerous communicative situations when communicators cannot switch over to each other's mother tongue, or none of them is a native speaker. So, English lingua franca may be 
defined as a unifying means of communication, a language-bridge or a communication vehicle (Brutt-Griffler, 2002, p. 126-137). English lingua franca is independent of social monitoring, its expanse cannot be checked and the number of its users is growing every day.

The communicative value of English lingua franca enables communication among people coming from a variety of cultural backgrounds and having different levels of linguistic competence. Thus, the success of the communication in question is much more important than the exact replication and imitation of the English native speaker. Intercultural communication is believed to be rather fragile due to the problems stemming from the participants' differences in norms and values. There is no denying the fact that the globalized world influences different domains of human activities including communication as the core of relationship between different values and languages with their norms as the tool of the communication efficiency. Since English lingua franca is de facto the tool and the means of vernacular communication (Jenkins, 2007, p. 154), it is seen as a necessity for people's every day activities in all spheres of life, and efficient communication is possible providing communicators talk the same language, share the same values and have common goals. So, sometimes English lingua franca is viewed as a certain threat to the national identity by a number of linguists who claim it might enhance the leveling of language diversity (Phillipson, 2008, p. 250-267).

The researchers of English lingua franca argue it might have a detrimental effect on the language users across the world. To start with, it can cause linguistic marginalization of certain languages. Then it may lead to language extinction with its further replacement by a dominant language, such as English. Further on, there might appear prejudices against non-users or poor users of English. And to crown it all, there eventually will be a shift in language teaching to focus exclusively on English. Even today English native speakers do not feel a great need to learn other languages, thus contributing to the increase of monolingualism (Pennycook, 1994; Phillipson, 1992). Critical attitude to the use of English lingua franca as an irresistible international language grows from its dominance over other languages resulting in imposing values from the centre to the periphery and wearing away distinctive cultural and national identities (Pennycook, 2002, p. 107119).

The beneficial nature of English lingua franca (ELF) is not as much critically reflected. The spread of ELF in various spheres can be explained by its role in the promotion of scientific and technological advances around the world stemming in the economically highly developed nations. According to the statistics, the number of English native speakers is around 400 million, and one quarter of the world's population (non-native speakers of English) can be reasonably fluent in English, moreover, about $80 \%$ of all interactions in English take place between non-native English speakers. The very thing that it is used so often by so many speaks to the fact that ELF has its communicative value and is a valuable linguistic resource. Empirical evidence suggests that although non-native English speakers have the most to lose if ELF continues to expand its power, they still acknowledge it as a valuable means of intercultural communication. The social position of ELF is of dual character: on the one hand it is criticized for its dominance over other languages; on the other hand it is appreciated as the most practical instrument of cross-cultural communication. So, ELF can both be a problem and a solution (Seargeant, 2012, p. 105). The issue of the ELF effectiveness is not yet fully researched or analyzed.

The purpose of the article is to highlight the communicative value of English lingua franca for effective cross-cultural interaction.

\section{METHODS}

The research exploited the theoretical analysis of scholarly sources with the following synthesis and generalization.

\section{RESULTS AND DISCUSSION}

As it has already been mentioned before, the effective communicative event does not account for the exact replication of the linguistic norms. Even if there are some deviations from the accepted 
standards of the language systems, the communication may still be quite successful given the fact that the communicators find themselves in the same discourse. Especially if they belong to the same professional culture, have common goals and share the same values. The functional range of ELF allows its users to be more flexible in expressing themselves without having to conform to certain norms or rules of the language. The language content of ELF proves to be modified and undergoing a process of de-standardization. There is a good excuse for such deviations from the norms as there is not any native speaker of such form of the linguistic phenomenon as ELF. Besides, the users' level of competence in the language may vary from proficient to very basic.

There has been a shift in the attitude and acceptance of ELF as a language unity recently with understanding of the necessity of its legalization, and recognition of the fact that its language systems have been formed and can be analyzed. As the number of ELF speakers is growing, the changes in its grammatical, lexical and phonetic systems become more and more obvious. It goes without saying that the analysis is conducted via comparison against Standard English language systems. It can be observed that the process of intercultural communication with English lingua franca as its instrument does not require from its participants any observance of certain rules or norms. Having suffered a number of deviations ELF ("expanding circle" according to Kachru (1989)) functions as a separate and independent form of English being free from its standards ("inner circle" according to Kachru (1989)).

ELF is sometimes viewed as a deviational form of the language, and its users as unsuccessful communicants or poor speakers of English. We are going to prove otherwise on the example of communicants belonging to the same professional culture and sharing the common knowledge in their domain. ELF takes its shape as an idiosyncratic form of the language thanks to the increase in its exploitation among professional users of certain spheres. All of them as a rule use ELF as a second language exclusively for professional purposes, and as ELF professional users they build a definite culture with its own standards. None of the ELF professional users is a native speaker of English, so there is no one who could be imitated or followed as an example of correctness. Besides, the aim of such communication does not revolve around correct employment of grammatical or lexical potential of English. Even if the participants of such intercultural communication feel free to forget about Sequence of Tenses, Suffixation as word-formation or Gerundial Constructions, there will be no failure in communication due to their concentration on the message (content), and not the form. We can look at a few samples of business letters both written by ELF professional users in the sphere of seafaring:

1) Subject: Requisition 040/2010e

Dear Capt. Tkachenko / CEng Pozhydayev,

Please let me have your explanation and reason for ordering:

Item 72 - 2 pcs pressure transmitter

Item 73 - 2 pcs resistance thermometer

Item 56 - 2 pcs lead acid, starter, flooded wet

Kind regards

Siegfried Pelzetter, Tech. Superintendent

2) Good day Dear Mr. S. Pelzetter,

Pls find in attachment answer Ch. Eng I. Pozhydayev regarding Requisition 040/2010e.

Brgds, Master S. Tkachenko

3) Dear Capt. Tkachenko / CEng Pozhydayev,

Tanks yours below.

I understood from your answer for

item 72 - pressure transmitter only one is actually needed.

Item 56 - understood, I'll investigate about charger and revert to you soonest.

Kind regards

Siegfried Pelzetter, Tech. Superintendent

Thus, we can witness complete understanding of the rendered problem from the prompt respond on part of both the communicators. However, English native speakers could find a number 
of deviations from the norms and rules. Both of the communicants are non-native English speakers, and they use ELF as the only practical tool of intercultural communication within the limits of their professional culture. Since none of them puts forward correct use of grammar forms or nice wording of the idea as a goal of communication, the priority here is the message. The success of the communication is achieved due to the fact that it takes place within the boundaries of the same domain. So, the content is more important than the form in situations with ELF being the instrument assisting cross-cultural exchange of values. We can consider more examples of correspondence within the same sphere of occupation:

4) Dear Captain Tkachenko,

We are still waiting of your reply about below email. It seems as if the lube oil samples are lost on the way to lab. If you have not the shipping details, please take the lube oil samples again.

Many thanks and best regards,

Sevim Acan

5) Dear Sir,

Pls be informed, that LO analysis was sent 31.07.2010 fm Manila. Pls advice, if this is not available in your office, we'll send asap again.

Brgds, Master S. Tkachenko

6) Subject: $A W$ : LO analysis

Dear Captain Tkachenko,

Thanks for your reply. Yes, please take the lube oil samples again.

Thanks and best regards,

Mrs. Sevim Acan

Quite obviously there is a tendency to minimize the effort produced in rendering the message of the letter. Here we can also observe the rule of saving the language effort in action. We can witness a certain way of formation of characteristic features of ELF language systems which could be described as de-standardization. The transmission of the message is not hindered by apparent discrepancy with the norms of Standard English. Here is another illustration of ignoring grammatical rules for the sake of quick transference of the main idea:

7) Dear Capt. Tkachenko /CEng Pozhydayev,

I've just learned from ZF (Maker of CPP/Gearbox) about a guarantee inspection of ZF Equipment was carried out during vessel's last call to Shanghai 10/09/10. Have I overseen your mail, I can't find any info from your side about this inspection.

Kind regards

Siegfried Pelzetter, Tech. Superintendent

So, as we can judge from the letters, alien deviated elements of the language are becoming effective instruments of cross-cultural communication providing they are used by communicants belonging to the same professional culture. At this point one can note that the process of destandardization could occur due to a very specific aspect of mastering a second language called fossilization. There is a moment in learning a language when the progress comes to a halt because of the interference of the first language. Thus, the employment of the second language is influenced by the first language, which leads to deviations of various kinds. Let us look at the example of such interference of the first language:

8) Dear Capt. Vygovsky and Ch.Eng. Mieserov,

Pls. let us know whether you receive the spare parts in Shanghai and can we close this gc? Many thanks.

Anke Wohlers, Technical Assistant, Guarantee-Claim Department

9) Good Morning, Dear Capt. R. Vygovsky,

Your message well received and noted, we will liaise closely with agent for berthing schedule and arrange as necessary; ensure that sludge \& garbage removal proceed smoothly. You may rest assured. See you on board upon berthing.

Best regards,

Wing Yih 
The question whether the English language should be "owned" by a limited number of users, namely native speakers, is of great importance. ELF researchers agree that the language is doomed to belong to all those who are more or less fluent in it and use it for different purposes (Wee, 2002, p. 282-295). In this case it will be possible to speak about sharing common values between periphery and central communities, rather than imposing the values from economically developed central communities on weaker peripheral groups with non-convenient geography. Provided the communicants use ELF for their interactions on cross-cultural level within the limits of common professional culture, the communication can be held directly without mediation of any other communication tool. There is no denying the fact that ELF is a mighty communication tool in itself. Since the number of people using this tool is increasing today, one can ascertain that ELF is a part of a certain culture with its values, norms and peculiarities. All the ELF users contribute to the evolution of this language form and promote its identity.

\section{CONCLUSIONS AND SCOPE FOR FURTHER RESEARCH}

To conclude, it is necessary to point out the impact of ELF on the linguistic situation in global scope. Of course, there are both positive and negative effects of the use of ELF for secure crosscultural communication, as the critical analysis of the affect of ELF expansion shows. Yet, the number of international institutions using ELF as a means of communication is growing, which demonstrates the power of such an effective communication instrument. The global linguistic order specifies the ways of ELF development. Increasing technology advancements promote and commit to the spread of English lingua franca all over the globe. With internet and immense craving for travelling, the scale of cross-cultural communication will be multiplied, and English lingua franca will contribute to its stability. In the perspective it is worth researching the peculiarities of ELF language systems. Whereas some will say it is not correct to analyze misuse or erroneous use of English, with obvious deviations from its norms, one should yet concentrate on the success of communication conducted with the help of English lingua franca. And the successful communication within the limits of the same professional culture is quite independent of the norms and standards. Thus, the process of the formation of ELF peculiarities is consistent and sustainable.

The scope for further research presupposes exploring the English lingua franca peculiarities in different professional cultures.

\section{REFERENCES}

Brutt-Griffler, J. (2002). World English: a study of its development. Clevedon, UK: Multilingual Matters.

Jenkins, J. (2007). English as a Lingua Franca: Attitude and Identity. Oxford: Oxford University Press.

Kachru, B. (1989). Teaching World Englishes. Cross Currents, 16(1), 15-21.

Pennycook, A. (1994). The cultural politics of English as an international language. London: Longman.

Pennycook, A. (2002). English, Politics, Ideology. In T. Ricento (Ed.), Ideology, Politics and Language Policies (pp. 107-119). Philadelphia: John Benjamins.

Phillipson, R. (1992). Linguistic Imperialism. Oxford: Oxford University Press.

Phillipson, R. (2008). Lingua franca or lingua frankensteinia? English in European integration and globalization. World Englishes, 27(2), 250-267.

Seargeant, P. (2012). The politics and policies of global English. In A. Hewings \& C. Tagg (Eds.), The politics of English: conflict, competition, coexistence (pp. 5-32). Abingdon: Routledge.

Wee, L. (2002). When English is not a mother tongue: Linguistic ownership and the Eurasian community in Singapore. Journal of Multilingual and Multicultural Development, 23(4), 282-295.

Надія Пожидаєва. Внесок англійської лінва франка до стабільності крос культурної комунікації. У статті розглядається феномен англійської лінгва франка i ii швидкого розповсюдження на території Свропи. Із зростанням процесів глобалізації кроскультурне усвідомлення неминуче сприятиме більш широкому використанню спільної мови для міжнародних взаємодій. Розширюване коло англійської мови інкорпорує такий ії різновид, що використовується виключно не носіями мови для міжкультурного спілкування. Немає жодного носія англійської лінгва франка. Таким чином, аналіз іiі функціональної цінності має бути сфокусованим на успішності комунікації, а не на кількості відхилень від норми. Функціональний діапазон 
англійської лінгва франка дозволяє використовувати ії більш вільно, не будучи пов'язаним з будьякими конкретними нормами або правилами. У статті проілюстровано вплив мовної ситуації в Європі на формування нового типу мови міжкультурної комунікації (англійська лінгва франка) 3 урахуванням особливостей професійної культури моряків. Було прийнято до уваги, що міжнародні моряки використовують англійську лінгва франка для спілкування як в усній, так і в письмовій формі, що сприяє процесу дестандартизації англійської мови. Контент-аналіз окремих текстів (уривків 3 професійної листування моряків) показує деяку незалежність комунікативного ефекту від правильної / неправильної граматичної та структурної форми висловлювання, що грунтується на використанні професійної підмови і її імпліцитному ефекті. Англійська лінгва франка живо стає комунікативним інструментом могутньої сили. Вона репрезентує певний культурний сегмент $\mathrm{i}$ зазнає усталеного розвитку.

Ключові слова: англійська лінва франка; лінгвістична ситуація; розширюване коло; успішна комунікативна подія; відхилення від норми; професіональна культура; комунікативний інструмент.

Received: January 30, 2019 Accepted: February 15, 2019 